\title{
Clinton's true colours on trade?
}

\section{There is a danger that President Bill Clinton, in seeking better terms of trade with Japan, will impoverish the rest} of us without improving the lot of the United States.

Mrs Margaret (now Lady) Thatcher, in her time, was fond of comparing national economies with those of ordinary households. Her presence might have been valuable at the meeting last week in Washington between President Bill Clinton and Mr Kiichi Miyazawa, the prime minister of Japan. Her homily might have gone like this. Nations are like households, right? Suppose that one of the largest, say $\mathbf{A}$, is living so far beyond its means that it has to borrow money from its friends to cover its domestic expenses. Suppose, further, that A's economic connections with its friends - B, C, D and the like - consist only of the sale among themselves of goods and services, perhaps the equivalent of a sack of vegetables for a pair of shoes. $\mathbf{A}$ (but also $\mathbf{B}, \mathbf{C}, \mathbf{D}$ and the others) then have a problem. If the quantity of goods and services on offer and the quantity of money in circulation remain fixed, $\mathbf{A}$ 's extravagance means that its debt to its friends grows year by year, while its friends cannot afford to buy everything that $\mathbf{A}$ would like to sell them.

The analogy should now be transparent. $\mathbf{A}$ is the United States, whose extravagance is most easily measured by the federal budget deficit. B, C, and D are the trading partners of the United States (but principally Japan), which finance the US deficit by capital transfers, either by buying US federal securities or, equivalently, by building factories or by buying real estate. Naturally, this willingness to help the United States live beyond its means is not sheer altruism: the lenders calculate that they will gain more in the long run from their investment than they lose in the short run from the consumption they forgo. So there is a trade imbalance as well. If there were not, overseas lenders would not have the funds to lend, and the whole burden of the US deficit would fall on US taxpayers, who would then have less to spend on purchases.

Evidently, from last week's proceedings, Clinton does not trust this simple arithmetic. He would like to make the trade imbalances go away, believing that US factories would then be working full-time again, turning out products for Japan and the other rich countries of the world. Whence the suggestions last week in Washington that the principles of the bilateral agreement on computer chips reached six years ago should be extended to other commodities. If not in as many words, Clinton is asking for a prearranged share for the United States in the Japanese domestic market in a variety of goods and services. Should not trade be 'fair' is what he asks? That would be correct if he simply means that the Japanese government should not stand between Japanese people and the goods and services US (or other) enterprises wish to sell them. But a quota system as Clinton seems to have in mind would impoverish us all, the United States included.

The Clinton recipe for managed trade, if successful and if extended beyond Japan, would lead to an entirely unexpected result - to a trading system indistinguishable from the discredited Soviet organization called Comecon, abandoned soon after Mr Mikhail Gorbachev's accession to power in 1986. That offered producers throughout the then Soviet bloc guaranteed outlets for their (often unwanted) goods. Comecon was one of the chief reasons why Soviet technology lagged behind that in the West for decades on end. It would be fanciful to suppose that Clinton seeks to recreate in the industrialized West an incubus like that, but that is the direction in which his policies are pointing.

But how else should a powerful country seek to rid itself of its trade deficit? The Thatcherian homily points to one way; if the budget deficit were made to vanish, as Clinton creditably avows it will, there would be no problem. (Dollars would be worth more yen, so that even the present volume of trade would be more nearly in balance.) Trade deficits would no doubt still exist, but they would be simply a measure of countries' relative productive efficiency and would be adjusted over time by movements in the value of different currencies.

But what is to happen in the many years before the US budget deficit melts away? Luckily, the caveats accompanying the household homily are not absolutes. The wealth to share among households is not fixed for all time, but can be increased. Technical change is one agent. International trade is another. And the two are linked. As the costs of development increase, international markets are essential to the commercial success of innovations. And innovations by advanced economies are essential means of vacating roles that can then be filled by countries now just on the edge of industrial manufacturing. It may be difficult to tell all this to people in places such as the United States who are still out of work, but Clinton should try. Bullying Miyazawa may be easier, and makes for better headlines, but is mistaken.

\section{Reactors and compromise}

President Bill Clinton's budget compromises are sending conflicting signals about his seriousness.

PRESIDENTS of the United States have no time to say where they stand on all the issues for which they are responsible. 